\title{
UNIVERSITY STUDIES OF FUTURE PSYCHOLOGISTS TO WORK WITH AUTISTIC CHILDREN
}

\author{
ALEKSANDER SHULGENKO \\ Faculty of Special Pedagogy and Psychology, \\ Dragomanov National Pedagogic University, 9 Turgenivska st., Kiev, Ukraine \\ E-mail address diakademia@mail.ru \\ IHOR OSTROVSKII \\ Faculty of Telecommunications, \\ @) $\odot \otimes \odot$ \\ Lviv Polytechnical National University, 12 Bandery st., Lviv, Ukraine \\ E-mail address: katerynaostrova@gmail.com
}

\begin{abstract}
The aim of the study. Help autistic children in Ukraine is inadequate due to a lack of well-trained specialists. This article is dedicated to the problem of preparation of specialists for the work with autistic children by the module system of higher education.

Methods. The methodological basis for constructing an educational module is to use the elements of graph theory, which can detect basic blocks, functions of the educational module, and identify the components of the content of the module and install interrelationships between them. To determine the content of the educational module were used the results of the survey of parents and professionals who work with autistic children. There have also been investigated indicators of 60 autistic children by Binet-Simon and CARS methods in the experimental and reference group. In the experimental group are specialists who have been trained by TEACCH method, whereas in reference group are specialists who do not have special education in the field of ASD.

Results. The results of the survey of parents and professionals as well as indicators of autistic children of experimental and reference group have shown a greater progress in development of autistic children in experimental group. Taking into account the results an educational modul for preparation of psychologists for work with autistic children was constructed. The modul consists of 8 blocks that include clinical, correctional and therapeutic knowledge and covers 5 functions of preparation of practical psychologists: diagnostical, predictive, corrective, coordinative and productive, that provides success in the development of autistic child.

Conclusions. Creation and the improvement of the contents of the modules, which deal with the question of autistic disorders, are interconnected with the quality of providing educational and correctional-teaching services for children and families in which they are educated.
\end{abstract}

Key words: module system of higher education, students, autistic children 


\section{INTRODUCTION}

An important task of higher education in Ukraine is to meet the needs of the state in specialists who can provide services professionally and effectively to persons with autism. Among the problems of the diagnosis there are components of social, psychological, educational areas, which should be solved by preparation of specialists for this nosology. Quality of training depends largely on the content of training, by the level of efficiency of compiling curricula, programs and manuals, which reflects the main components of the preparedness of graduates to work with sick children. The fact that autism is a disease of the mental sphere of the child is confirmed by the clinical phenomenology, etiology and pathogenesis of autistic disorders (Lebedinska, 1991; Nikolska, 1997). The universality of the phenomenon of autism in the psychology of childhood is caused by the peculiarities of the nervous system ontogeny and individual development of the child taking into account genetic factors and the external environment. Specified by Leo Kanner as distorted mental development, autism represents range of disorders that are characterized by low mental tone, low level of contact with others, speech disorders, motor skills, stereotypical activities and behavior that form the basis for social exclusion. Autism was studied first in psychiatry and gradually became a problem in the social sphere: how to educate, train, build required social skills. This system of outstanding issues concerns doctors, teachers, and social workers. The main question of who should be expert on autistic children, is not solved unfortunately today at the state level.

However, despite the lack of special schools for autistic children in Ukraine for nearly ten years correctional pedagogics investigate this problem on two main levels: specialist training to work with the young people and the development of special education content. At the same time, at the Institute of Special Education and Psychology of Dragomanov National Pedagogic University (Syniov, 2008; Sheremet, 2007; Shevtsov, 2006; Shulzhenko, 2009) training programs were improved and expanded for the purpose of introduction into the structure of education a module that reflects autism problems in its content.

The aim of our research is curriculum development for preparing students-psychologists for work with autistic children.

\section{EXPERIMENTAL METHODS}

The methodological basis for constructing an educational module is to use the elements of graph theory, which can detect basic blocks, functions of the educational module, and identify the components of the content of the module and install interrelationships between them. Detail information about graph theory one can obtain elsewhere (Trochymchuk, 1998).

To determine the content of the educational module were used the results of the survey of parents and professionals who work with autistic children. Two types of questionnaires were used for this purpose. The first one contains of 18 items, which reflect different areas of therapeutic influence on autistic child (behaviour, emotion, intellect, etc.) as well as others factors, e.g. education (skill) of spe- 
cialists, structuration of space and time, etc., which are necessary for child development. The second questionnaire offers rating estimation of factors for positive future development of the child: a high level of financial and material support of the institution, which the autistic child attends; a high level of methodical help; the presence of a team of specialists, which includes a doctor, a teacher, a psychologist, a specialist in communication, art therapists and other professionals; psychological conditions for harmonization of the conduct of the child. Rating estimations of the parents and professionals should determine the priority areas of the autistic children development and specify the main aspects of curriculum for preparation of specialists.

There have also been investigated indicators of autistic children in the experimental and reference group. The experimental group consists of 30 school age autistic children from the first experimental school in Ukraine where the children with autism are officially taken for studying. The specialists of the school were trained by TEACCH method for more than 2 years. The reference group includes 30 school age autistic children from various inclusive schools of Lviv and Kiev. But the specialists of these schools have not special education in the field of ASD or have only single training on ABA therapy.

The following methods were used in the research:

1. Binet-Simon scale for intelligence level determination (Kamin, 1995).

2. Method of neuropsychological research according to Alexander Luria for psychophysical development level determination (Akhutina, Pylaeva, 2011).

3. Childhood Autism Rating Scale (CARS) for autism level determination (Chlebowski, Green, Barton, Fein, 2010).

It was expected that this study will enable us to define the features of cognitive development of children with autism in experimental and reference group, which in turn will improve compilation curriculum for preparation of psychologists to work with chidren with ASD.

The results were processed by statistical methods. Accordingly, a comparative analysis was used to interpret the results and to obtain objective conclusions.

\section{EXPERIMENTAL RESULTS AND THEIR DISCUSSION}

A problem of student training for working with autistic children, raised in our previous publications, based on the assumption that with the advent of each new nosology of children, which in its clinical and diagnostic psychological characteristics significantly differs from other nosology needs a new paradigm of educational content and is provided by a sufficient level of quality of knowledge and skills of graduates in the directions of correction pedagogics, special psychology and speech therapy with the transition to a modular system of education.

One of the objectives of our study is to introduce the module "Correction psycho pedagogics of autistic disorders in children" in student education at the Department of Special Education.

To determine the content of the module we carried out an analysis of problems of autistic children and their families in our country. Investigations were conduc- 
ted by students and graduate students of psychology and special medicine among two groups: 1) parents and friends of autistic children, 2) professionals who work in educational and rehabilitation facilities, where among other disabled children (mentally retarded children) are children with autism spectrum disorders. The largest range of problems are educational issues in the event the institution and the way training is not available or causes difficulties in children. This may include a lack of inclusive and integrative learning in regular schools, and especially in special schools for children with intellectual disabilities and speech disorders. Unpreparedness of teachers not only in general schools, but also in special schools to provide appropriate educational services to autistic children has meant that 50 $\%$ of children are educated at home. Clearly the quality of education is related to the quality of life of persons with autism, which is at a sufficiently low level.

According to the research of Dina Shulzhenko, Kateryna Ostrovska communication problems of autistic people make up the basis of social, educational, developmental abilities of the child to receive from other people the cognitive, emotional, behavioral information and share it (Shulgenko, 2005; Ostrovska, 2012). Disturbance of the communicative structure of the autistic child leads to behavioral disturbances, which refer to the main signs of autism. However, the practice of effective correction of autistic disorders confirms that harmonization of behavior occurs due to a formation of motives to communicate with an autistic child. Aggressive, auto aggressive tendencies disappear when as a result of remedial intervention a child loses alarm and comes into contact.

\section{THE RESULTS OF SURVEY OF PARENTS AND PROFESSIONALS}

The first figure shows data of survey of professionals who work with autistic children. The survey was conducted in Ukraine, Germany, Poland, Slovakia, England. The number of investigated people reached to 250. Among the urgent problems to be solved are the following: $50 \%$ - the issue of content of special education, $23 \%$ - believe that it is necessary to solve communication problems, $14 \%$ - behavioral, $7 \%$ - social welfare, $5 \%$ - the issue of regulation and self-control of emotions and $4 \%$ - believe that it is necessary to address the issue of professionally forecasting further development.

Thus the analysis of autistic problems by specialists of educational and rehabilitation centers showed that the most vulnerable are educational programs, and especially the issue of content, process, tools and methods of teaching autistic children. They suggest solving educational problems, that provides a prediction of child development, the importance of which underlined by only 4 $\%$ professionals. In the same educational and correctional process we should overcome behavioral, affective-regulation, social and domestic problems characteristic of autistic disorders in children. Another aspect are the communication difficulties in children that lead, according to experts, to a number of social problems. Important, in their opinion, is overcoming autism by use of an educational technology system. 


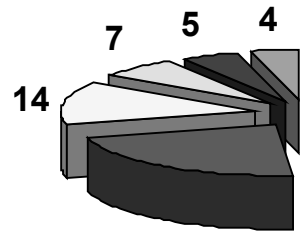

23

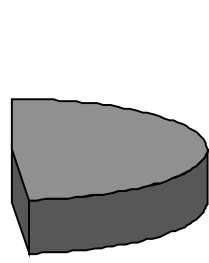

50 $\square$ social welfare

$\square$ self-control and emotion

$\square$ forecast development

Fig. 1. Distribution of teachers answers as for the main problems of autistic children. Source:Own chart.

Unlike the professionals who work with autistic children, 175 families surveyed consider, that the main role in a correctional system should concentrate on difficulties of behavior and emotional regulation of children. Inconsistency in the use by parents of conventional methods and techniques of education (punishment, promotion, interviews, review books, children's programs, etc.) lead to the strengthening and deepening of autistic manifestations in children (abstaining from food, anxiety, phobias, cries, vocalizations, etc.).

Also, is a fairly long period of time when autistic children and their parents make for each other huge problems that manifest themselves in desperation, frustration, aggression towards the child. Not all parents can understand that due to stereotypic actions autistic children try to get attention, to harmonize communication or even meet the needs of their cognitive sphere. For example, twisting arms can be a way to activate communication of children with their families. However, such methods cite the reluctance of parents to interact with the child, to understand what he/she wants to say, to tell him/her and encourage communication.
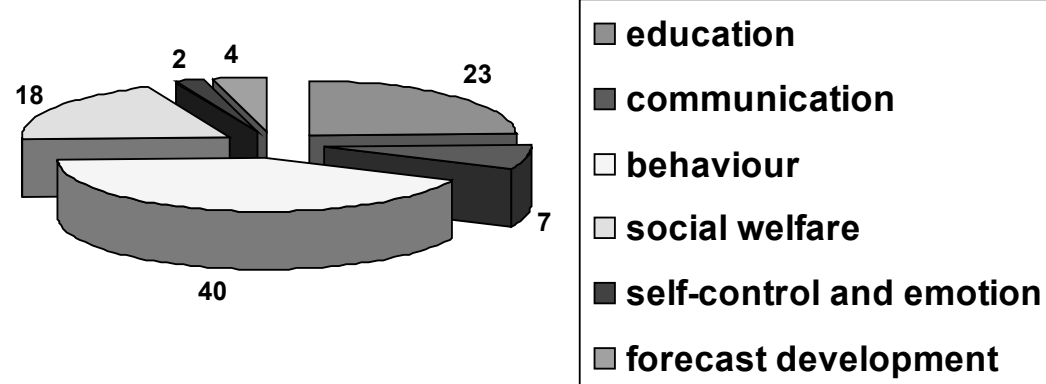

Fig. 2. Distribution of parents answers as to the main problems of autistic children. Source:Own chart.

Analysis of figure 2 shows that in contrast to the teachers, the parents do not attach much importance to education of their children, knowing that their willingness to study is strongly blocked by autistic disorders and lack of cogni- 
tive activity in children. After receiving and analyzing the results of a survey of teachers and parents, we offered to parents to explain how they understand a forecast of an autistic child's development. Respondents obtain the questionnaire, which offers rating estimation of factors for positive future development of the child: a high level of financial and material support of the institution, which the autistic child attends; a high level of methodical help; the presence of a team of specialists, which includes a doctor, a teacher, a psychologist, a specialist in communication, art therapists and other professionals; psychological conditions for harmonization of the conduct of the child. According to a conducted survey a hierarchy of values for the parents has the following appearance: specialist, psychological conditions, provide guidance, a team of specialists, material and financial support.

Thus, the solution to the problem of autism consists in the formation of skills, knowledge and competences in a specialist who knows direct corrective techniques to overcome autistic disorders.

\section{The results of investigation of autistic children indicators}

The use of A.Bine - T. Simon method gave us the following results. For most autistic children average mental development indices were lower than those corresponding to biological age but essentially differ in experimental and reference group. Thus for experimental group average mental indices were ranging from 4 years to 12 years and 10 months. For children of reference group averages incices of mental development were lower than those of biological age within 2 years 9 months to 6 years 9 months. The results demonstrate substantial development of children in experimental school comparing to children from reference group.

Comparative analysis of the study (by CARS method) shows that compared with children of experimental group in children of reference group the following areas were worse developed: relationships with people, emotional reaction, use of objects, adaptation to change, visual and auditory reaction, shyness, verbal communication, the level of activity. These criteria indicate the presence in the children more expressed so-called autism triad. They touched an emotional reaction, establishing social contacts and available stereotyped action. We also observe a bad adaptation of children of reference group to changes and increased levels of shyness and nervousness compared with children with experimental group (see Table 1). According to the comparative analysis for two investigated groups the total score for the CARS technique in children of reference group is higher than that in children of experimental group.

We also conducted a neuropsychological method by A.R. Luria and got the following result: the cognitive development of children with ASD of control group is higher than that in children with reference group (see Table 1).

The obtained results show that good qualified specialists who work with autistic children in experimental group can achive greater success. The specialists of experimental school were trained in TEACCH method. So, components of this program should be introduced in curriculutm for preparation of psychologists to work with autistic children. 
Table 1. A comparison of indeces for two ASD groups (Std.Dev.-standard deviation

\begin{tabular}{|c|c|c|c|c|}
\hline & \multicolumn{2}{|c|}{ reference group } & \multicolumn{2}{|c|}{ exper. group } \\
\hline & Mean & Std.Dev. & Mean & Std.Dev. \\
\hline orientation & 1.10 & 0.10 & 0.63 & 0.09 \\
\hline adequacy & 1.30 & 0.17 & 0.86 & 0.1 \\
\hline criticality & 1.45 & 0.17 & 0.81 & 0.08 \\
\hline proof test & 1.90 & 0.20 & 2.45 & 0.26 \\
\hline reciprocal coordination & 1.50 & 0.18 & 2.13 & 0.29 \\
\hline ability to make choice & 2.10 & 0.27 & 2.18 & 0.29 \\
\hline dynamic praxis & 1.35 & 0.12 & 1.90 & 0.20 \\
\hline coping. simple figures & 1.35 & 0.14 & 1.63 & 0.12 \\
\hline off fingers & 1.45 & 0.18 & 1.59 & 0.19 \\
\hline oral gnosis & 1.00 & 0.10 & 1.00 & 0.14 \\
\hline objective gnosis & 1.00 & 0.11 & 1.63 & 0.12 \\
\hline acoustic gnosis. & 1.45 & 0.15 & 1.13 & 0.16 \\
\hline spatial figures & 1.55 & 0.15 & 2.09 & 0.25 \\
\hline recognition of emotions & 1.50 & 0.11 & 2.22 & 0.22 \\
\hline overall impression & 1.42 & 0.17 & 1.15 & 0.13 \\
\hline movements and actions & 1.48 & 0.18 & 1.67 & 0.19 \\
\hline gnosis & 1.27 & 0.12 & 1.81 & 0.22 \\
\hline relationships with people & 2.30 & 0.27 & 1.40 & 0.13 \\
\hline imitation & 1.70 & 0.15 & 1.63 & 0.16 \\
\hline emotional response & 2.35 & 0.26 & 1.59 & 0.15 \\
\hline characteristics body & 2.10 & 0.24 & 1.86 & 0.23 \\
\hline using objects & 1.90 & 0.20 & 1.36 & 0.19 \\
\hline adapting to change & 2.00 & 0.26 & 1.04 & 0.15 \\
\hline visual reaction & 2.20 & 0.24 & 1.72 & 0.16 \\
\hline auditory reaction & 2.00 & 0.27 & 1.36 & 0.19 \\
\hline sensitivity & 1.55 & 0.17 & 1.09 & 0.20 \\
\hline timidity & 2.20 & 0.25 & 1.63 & 0.15 \\
\hline verbal communication & 2.70 & 0.27 & 2.04 & 0.22 \\
\hline nonverbal communication & 2.30 & 0.25 & 1.81 & 0.26 \\
\hline activity level & 2.55 & 0.29 & 1.50 & 0.15 \\
\hline intellectual development & 2.55 & 0.24 & 2.72 & 0.260 \\
\hline $\begin{array}{c}\text { overview } \\
\end{array}$ & 2.30 & 0.24 & 1.27 & 0.16 \\
\hline age & 7.90 & 2.63 & 10.3 & 2.24 \\
\hline psychological age & 4.17 & 1.33 & 5.68 & 2.26 \\
\hline
\end{tabular}

\section{Development of curriculum}

As above mentioned a modular approach in student training for working with autistic children provides personal and content aspects of solving the problem of autism (Syniov, 2008). One method of drawing up curricula and training programs for correctional educators is an organization of modular training. In recent 
years this area has seen many developments. The essence of modular training consists of maximum separation of certain blocks (modules) of training material. Each module, in its study, achieves some didactic purpose. Training material covered by a module must be so complete that it was possible to design a single unit with separate modules without disturbing the consistency of presentation.

Modular training provides maximum independent work. The functions of the teacher in this study are more confined to the advisory. Taking into account the modular structure we propose the following method of module formation. Construct a graph of the logical structure of the subject, setting out not only intra- subject, but also interdisciplinary communication. Then some educational elements, constituting the structure of the module, the topics are selected due to logical structure of the graph that are essential for the study of specific educational elements and the whole subject.

As was noted earlier, train professionals in the field of psychology and special correctional psychopedagogics that meet modern requirements, promote continuous improvement of curricula, so that they always meet the requirements of a specialist.

These changes are associated with the process of differentiation and integration of learning. Differentiation is associated with increased educational significance of individual items. It is expressed in the transformation of some disciplines in the course. So at the time discipline Psychology of mental retardation evolved in the courses such as Special psychology, Psychocorrection and psychoadvisory, Special child psychology, Methods of the psychologist in special schools.

There is a reverse process - integration. With the reduction of proportion of individual subjects, they can be excluded from courses or decreased or enter into other disciplines. So a course Correction work with children who have a combined defects is included as a module in the course Special Psychology and Special Education.

At this time the amount of courses in the curricula of universities in all probability has already reached its upper limit. Therefore, the introduction of a new course or courses must be combined with the reduction of others, but not by removing them from education, and by combining the former components based on their content integration. So a separate module can be introduced as a course Correction work with children who have intellectual and autistic disorders.

The main problem in the work with autistic children is that psychologists specialized in this field do not adequately understand and do not perform their duties and responsibilities. So, to prepare psychologists to this work we base it on the American experience of training modulus as well as the peculiarities of work with autistic children in Ukraine. Thus, a modular software and content of training can be presented by Figure 3 , which includes the fol-

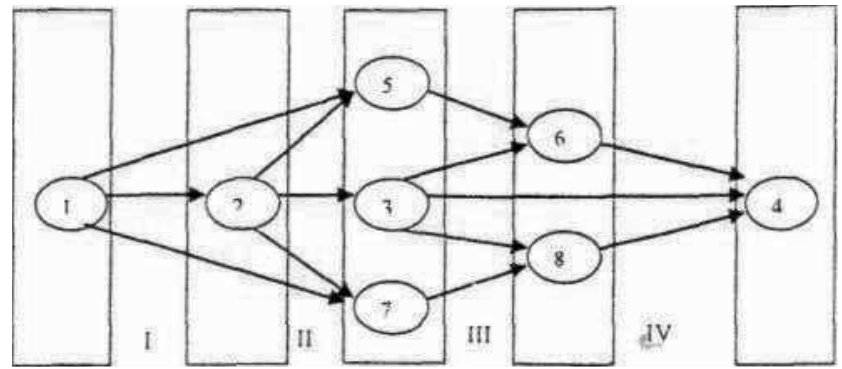

Fig. 3. Graph of education module for preparation of specialists in autism

Source:Own chart. 
lowing functions and responsibilities. Contour I - Diagnostic function of practical psychology, Contour II - predictive function of practical psychology, Contour III - Correction feature practical psychologist, Contour IV - Methodological and practical psychologist coordinating function between professionals and parents, Contour $\mathrm{V}$ - productive function of practical psychology. In addition the module includes 8 blocks directed to preparation of psychologist competences:

1) Clinical foundations of autistic disorders;

2) Classification and differentiation of autistic disorders;

3) The content of special education, remedial training and education of autistic children;

4) Correction technology to overcome autistic disorders;

5) The principles of correction and social prognosis of autistic children;

6) Special methods of teaching and the education of children with autism defects (program inclusive and integrative learning);

7) A special method of forming the social and communicative sphere of autistic children;

8) Methods of work with parents and family of autistic children.

This method based on modular system covers most parent questions, is able to resolve all the difficulties encountered in the correction process. The modules are organically connected and their content is aimed at achieving goals - social competence and quality of life of an autistic child.

The basis for a new paradigm of the module were the results of interviews, surveys and questionnaires 70 students 5 th year of full-time and part-time teaching. At preparation to state exams we proposed an innovative modular approach to study the course. Under the proposed scheme educational material was divided into modules, which according to the students estimation contributed to a much more efficient process of refinement and consolidation of knowledge.

According to that state exams integrate knowledge and skills from the system of concepts and categories, trends remedial help, especially the mental development of children with special needs, diagnosis and prognosis of further social life. We have included these components into the modular course. As a result of such a construction module all the surveyed students indicated that the material is absorbed easier, more interesting, more specifically and accurately. So for each module, students write an essay or prepare a discussion or develop a simulation game, thus fixing the flaws and white spots of their knowledge and skills.

Analyzing the title and content of the module, students indicated that they considered and handled most important components, important basic aspects of correctional work with categories of children with intellectual disabilities, which include mentally retarded children, children with cerebral palsy and autism disorders.

\section{CONCLUSIONS}

The paper concerns to preparation of specialists for the work with autistic children by the development of curriculum for higher education. For elaboration of the curriculum two categories of autistic children (experimental and reference 
group) as well as their parents and specialists were analysed. The experimental group consists of 30 school age autistic children from the first experimental school in Ukraine, specialists of which were trained by TEACCH method for more than 2 years. The reference group includes 30 school age autistic children from various inclusive schools of Lviv and Kiev. But the specialists of these schools have not special education in the field of ASD or have only single training on ABA therapy.

The analysis of questionnaires of parents and specialists as well as indicators of autistic children of experimental and refrence group have shown a greater progress in development of autistic children in experimental group. Taking into account the results an educational modul for preparation of psychologists for work with autistic children was constructed. The modul consists of 8 blocks that include clinical, correctional and therapeutic knowledge and covers 5 functions of preparation of practical psychologists: diagnostical, predictive, corrective, coordinative and productive, that provides success in the development of autistic child. The main parts of education module were developed and introduced in University practice.

\section{REFERENCES}

Akhutina, T.V., Pylaeva, N.M. (2011) L.Vygotsky, A.Luria and development neuropsychology. Psychology in Russia: State of the Art, 155-175.

Chlebowski, C., Green, G.A., Barton, M.L., Fein, D. (2010) Using the Childhood Autism Rating Scale to Diagnose Autism Spectrum Disorders. Journal of Autism and Developmental Disorders. 40 (7), 787-799.

Lebedinska, K.S, Nikolska, O.S. (1991). Диагностика раннего детского аутизма [Diagnostics of early childhood autism]. Moscov: Просвещение.

Kamin, L. J. (1995). The pioneers of IQ testing. In Ressell Jacoby \& Naomi Glauberman (Eds.), The Bell Curve Debate: History, Documents, Opinions. New York: Times Books.

Nikolska, O.S., Baenskaya, E.R., Libling, M.M. (1997). Аутистичный ребенок: Пути помощии [Autistic child: way of helpness]. Moscov: Просвещение.

Ostrovska, K.O. (2012). Peculiarities of social competence of children with different autistic level. Journal of Education Culture and Society, 1, 133-147.

Sheremet, M.К. (2007). Проблеми та перспективи специіальної освіти [Problems and prospects of special education]. Kamianets-Podilskyj: ПП Мошинський В. С.

Shevtsov, A.G. (2006). Підготовка кадрів для системи спеціальної освіти та реабілітації осіб з інвалідністю у світлі Болонського процесу [Preparation of specialists for special education and rehabilitation of disables in the framework of Bolon process]. Kiev: Вища освіта України.

Shulgenko, D.I., Lisinchuk, O.V. (2005). Робота гувернера-психопедагога з корекиії інтелектуальних та аутистичних порушень у дітей [Work of tutor-psychopedagog with correction of intellectual and autistic disorders in children]. Kiev: Національний педагогічний університет імені М.П. Драгоманова.

Shulzhenko D.I. (2009). Основи психологічної корекиії аутистичних порушень у дітей: монографія [Base of psycholocial correction of children autistic disorders]. Kiev: Нац. пед. ун-т ім. М.П.Драгоманова.

Syniov, V.M. (2008). Мультидисциилінарний (медико-психолого-педагогічний) характер діагностики і корекції розвитку особистості при порушеннях процесу соијалізації [Multidisciplinary (medical, psychological and pedagogical) nature of the diagnosis and correction of personal development in violation of the socialization process]. Kiev: Нац. пед. ун-т ім. М.П.Драгоманова, 527 - 532.

Trochymchuk R.M. (1998) Теорія графів [Graph theory], Kiev: Редакційно-видавничий центр “Київський університет". 